\title{
PERBEDAAN ANTROPOLOGI HUKUM, SOSIOLOGI HUKUM DAN HUKUM ADAT
}

\author{
IRMA DEATINY SANJAYA \\ Email: Irmadestiny28@icloud.com \\ No BP: 2010003600371 \\ Fakultas Hukum Universitas Eka Sakti Padang
}

\section{A. PENDAHULUAN}

Antropologi adalah ilmu pengetahuan (logos) tentang manusia (antropos) sehingga antropologi hukum adalah ilmu pengetahuan yang berkaitan dengan manusia dan kaitannya dengan hukum. Manusia yang dimaksud disini adalah manusia yang hidup bermasyarakat, bergaul antara yang satu dan yang lain, baik masyarakat yang masih sederhana budayanya (primitif) maupun yang sudah modern (maju) budayanya. Sedangkan budaya yang dimaksud disini adalah budaya hukum. Budaya Hukum yaitu segala bentuk perilaku budaya manusia yang mempengaruhi atau yang berkaitan dengan masalah hukum.

Sasaran pokok dalam antropologi adalah manusia, baru kemudian perilaku budayanya, tidaklah sebaliknya sebagaimana dalam ilmu yang lain. Dikarenakan perbedaan tempat dan lingkungan, perbedaan sejarah dan asal-usulnya, perbedaan semangat dan jiwanya, perbedaan akal dan cara berpikirnya, perbedaan budaya dan agama yang mempengaruhinya, maka perilaku budaya manusia itu berbeda-beda antara yang satu dan yang lain. Jadi tidak ada suatu sistem pola perilaku manusia yang seragam, dan oleh karenanya tidak ada pula sistem pola kepribadian manusia itu yang sama.

Antropologi melihat hukum itu hanya sebagai suatu aspek dari kebudayaan yaitu suatu aspek yang digunakan oleh kekuasaan masyarakat yang teratur dalam mengatur perilaku manusia dan masyarakat agar tidak terjadi penyimpangan dan agar penyimpangan yang terjadi dari normanorma sosial yang telah ditentukan dapat diperbaiki. Dengan demikian adat masyarakat yang menjadi suatu sistem kontrol sosial itu akan mempunyai kekuatan hukum, apabila ia digunakan oleh kekuasaan masyarakat. Sebagaimana dikatakan Hoebel: "Hukum itu ada pada masyarakat yang sederhana dengan hukumnya yang sederhana atau primitive law, hukum itu ada pada masyarakat purba dengan hukumnya yang purba atau archaic law, dan hukum itu ada pada masyarakat yang telah maju dan hukumnya yang modern.

Antropologi hukum pada dasarnya mempelajari hubungan timbal-balik antara hukum dengan fenomena-fenomena sosial secara empiris dalam kehidupan masyarakat; bagaimana hukum berfungsi dalam kehidupan masyarakat, atau bagaimana hukum bekerja sebagai alat pengendalian sosial (social control) atau sarana untuk menjaga keteraturan sosial (social order) dalam masyarakat.

Jika kita hubungan dengan sifat manusia sebagai makhluk sosial (zoon politicon) yang

mana manusia hidup bersama orang lain. Dalam hidup bersama, tentu seorang manusia tidak dapat bertindak seenaknya. Norma meletakkan pedoman dasar bagaimana manusia memainkan perannya dan bagaimana manusia berhubungan dengan sesamanya. Akan tetapi sering kali terjadi adanya norma-norma diindahkan. Terjadi berbagai penyimpangan sosial. Akibatnya, timbul kekacauan dalam masyarakat.

Sosiologi hukum sendiri mempunyai objek kajian fenomena hukum, sebagaimana telah dituliskan oleh Curzon, bahwa Roscou Pound menunjukkan studi sosiologi hukum sebagai studi yang didasarkan pada konsep hukum sebagai alat pengendalian sosial. Sementara Llyod, memandang sosiologi hukum sebagai suatu ilmu deskriptif, yang memanfaatkan teknis-teknis empiris. Hal ini berkaitan dengan perangkat hukum dengan tugas-tugasnya.Ia memandang hukum sebagai suatu produk sistem sosial dan alat untuk mengendalikan serat mengubah sistem itu. 


\section{B. PEMBAHASAN}

\section{Antropologi Hukum}

Antropologi adalah salah satu cabang ilmu sosial yang mempelajari tentang budaya

masyarakat suatu etnis tertentu. Antropologi lahir atau muncul berawal dari ketertarikan orangorang Eropa yang melihat ciri-ciri fisik, adat istiadat, budaya yang berbeda dari apa yang dikenal di Eropa. Antropologi mempunyai bidang kajian sendiri yang dapat dibedakan dengan ilmu sosial lainnya, yang salah satunya seperti sosiologi, dan ilmu sosial lainnya. Antropologi juga dapat dikelompokkan ke dalam cabang ilmu humaniora karena kajiannya yang terfokus kepada manusia dan kebudayaannya. Sebagaimana sudah dijelaskan bahwa, secara umum dapat dikatakan antropologi merupakan ilmu yang mempelajari manusia dari segi keragaman fisiknya, masyarakatnya, dan kebudayaannya.

Antropologi hukum pada dasarnya adalah subdisiplin ilmu hukum empiris yang memusatkan perhatiannya pada studi-studi hukum dengan menggunakan pendekatan antropologis. Kendati demikian, dari sudut pandang antropologi, sub disiplin antropologi budaya yang memfokuskan kajiannya pada fenomena empiris kehidupan hukum dalam masyarakat secaraluas dikenal sebagai antropologi hukum. Antropologi hukum pada dasarnya mempelajari hubungan timbal-balik antara hukum dengan fenomena-fenomenasosial secara empiris dalam kehidupan masyarakat; bagaimana hukum berfungsidalam kehidupan masyarakat, atau bagaimana hukum bekerja sebagai alat pengendalian sosial (social control) atau sarana untuk menjaga keteraturan sosial (social order) dalam masyarakat. Dengan kata lain, studi-studi antropologis mengenai hukum memberi perhatian pada segi-segi kebudayaan manusia yang berkaitan dengan fenomena hukum dalam fungsinya sebagai sarana menjaga keteraturan sosial atau alat pengendalian social.

Dalam perspektif antropologi, hukum adalah bagian integral dari kebudayaan secara

keseluruhan, dan karena itu hukum dipelajari sebagai produk dari interaksi sosial yang dipengaruhi oleh aspek-aspek kebudayaan yang lain, seperti politik, ekonomi, ideologi, religi, dan lain lain. Di sisi yang lain hukum juga dipelajari sebagai proses sosial yang berlangsung dalam kehidupan masyarakat. Ini berarti secara empiris dapat dijelaskan, bahwa hukum yang berlaku dalam masyarakat selain terwujud dalam bentuk perundang-undangan (hukum positif), juga berwujud sebagai hukum agama dan hukum adat. Tetapi, secara antropologis bentuk mekanisme-mekanisme pengaturan sendiri dalam komunitas-komunitas masyarakat adalah juga merupakan hukum yang secara lokal berfungsi sebagai sarana.

\section{Sosiologi Hukum}

Sosiologi merupakan studi hukum dalam perspektif ilmu sosial merupakan sebuah

ikhtiar melakukan konstruksi hukum yang didasarkan pada fenomena sosial yang ada. Perilaku masyarakat yang dikaji adalah perilaku yang timbul akibat berinteraksi dengan sistem norma yang ada. Interaksi itu muncul sebagai bentuk reaksi masyarakat atas diterapkannya sebuah ketentuan perundang-undangan positif dan bisa pula dilihat prilaku masyarakat sebagai bentuk aksi dalam memengaruhi pembentukan sebuah ketentuan hukum positif.

Contoh yang dapat digambarkan dalam model studi hukum dalam perspektif sosial 
adalah misalnya studi tentang hukum pertanahan tentang pengadaan tanah untuk kepentingan umum. Kita bisa mulai dari aturan perundang-undangan yang berlaku yang mengatur masalah pengadaan tanah untuk kepentingan umum. Apakah ada ketidaksesuaian antara peraturan perundangan dengan kondisi masyarakat, sehingga menimbulkan konflik ketika pemerintah melakukan pembebasan tanah dan seterusnya.

Dengan demikian, kajian sosiologi hukum adalah suatu kajian yang objeknya fenomena hukum, tetapi menggunakan optik ilmu sosial dan teori-teori sosiologis, sehingga sering disalahtafsirkan bukan hanya oleh kalangan non hukum, tetapi juga dari kalangan hukum sendiri. Yang pasti kajian yang digunakan dalam kajian sosiologi hukum berbeda dengan kajian yang digunakan oleh Ilmu Hukum seperti Ilmu Hukum Pidana, Ilmu Hukum Perdata, Ilmu

Hukum Acara, dan seterusnya. Persamaannya hanyalah bahwa baik Ilmu Hukum maupun Sosiologi Hukum, obyeknya adalah hukum.

Definisi Sosiologi Hukum Menurut Para Pakar, Soerjono Soekanto, Sosiologi hukum adalah suatu cabang ilmu pengetahuan yang secara analitis dan empiris menganalisis atau mempelajari hubungan timbal balik antara hukum dengan gejala-gejala social lainnya. Satjipto Rahardjo, Sosiologi hukum (sociology of law) adalah pengetahuan hukum terhadap pola prilaku masyarakat dalam konteks sosialnya. R. Otje Salman Sosiologi hukum adalah ilmu yang mempelajari hubungan timbal balik antara hukum dengan gejala-gejala sosial lainnya secara empiris analitis.

Sosiologi hukum adalah ilmu yang mempelajari hubungan timbal balik antara hukum dengan gejala-gejala sosial lainnya secara empiris analitis. Menurut Brade Meyer:

Sociology af the law-Menjadikan hukum sebagai alat pusat penelitian secara sosiologis yakni sama halnya bagaimana sosiologi meneliti suatu kelompok kecil lainnya. Tujuan penelitian adalah selain untuk menggambarkan betapa penting arti hukum bagi masyarakat luas juga untuk menggambarkan proses internalnya hokum.

Sociology in the law-Untuk memudahkan fungsi hukumnya, pelaksanaan fungsi hukum dengan dibantu oleh pengetahuanatau ilmu sosial pada alat-alat hukumnya.

Gejala sosial lainnya-Sosiologi bukan hanya saja mempersoalkan penelitian secara normatif (dassollen) saja tetapi juga mempersoalkan analisa-analisa normatif didalam rangka efektifitas hukum agar tujan kepastian hukum dapat tercapai.

\section{Hukum Adat}

Hukum adat memandang masyarakat sebagai paguyuban artinya sebagai satu hidup bersama, dimana manusia memandang sesamanya sebagai satu bersama, dimana manusia memandang sesamanya sebagai tujuan, dimana perhubungan-perhubungan manusia menghadapi sesama manusia dan segala perasaannya, dengan segala sentimen sebagai cinta, benci, simpati dan antipasti sebagai yang baik dan kurang baik selaras dengan pandangannya atas masyarakat, maka di hadapilah oleh hukum adat manusia itu dengan kepercayaan sebagai orang yang bertabiat anggota masyarakat.

Hukum adat merupakan hukum asli Indonesia yang tidak terkodifikasi dalam peraturan perundang-undangan nasional. Hukum yang sejak dahulu telah ditaati oleh masyarakat adat di berbagai daerah di Indonesia, dan di akui hingga sekarang sebagai salah 
satu hukum yang sah, hukum yang sepenuhnya berlaku di Tanah Air. Banyak contoh yang mengakui kedudukan hukum adat dam hukum islam di Indonesia dapat dilihat dari pembentukan undang-undang yang isinya mencorakkan hukum adat dan hukum Islam dari undang-undang perkawinan, UUPA, dan juga Salah satu ciri yang signifikan dalam unsur hukum adat dengan adanya peleburan ajaran agama yang tak mungkin dikesampingkan karena masyarakat Indonesia tak lepas dari unsur agama yang menjadi dasar dalam pemberlakuan hukum adat.

Saat ini, hukum adat masih diterapkan oleh berbagai masyarakat adat Indonesia, hukum yang mengatur perihal warisan adat, perkawinan adat, dan hal-hal lain yang mengatur regulasi dalam suatu budaya kultural. Jenis hukum tertua yang pernah dimiliki oleh Indonesia sampai saat ini masih diterapkan oleh masyarakat, dan diakui oleh negara.

Istilah hukum adat adalah merupakan terjemahan dari istilah (bahasa) Belanda "Adat Recht" yang awalnya dikemukakan oleh Prof. Dr. Christian Snouck Hurgronje nama muslimnya H. Abdul Ghafar di dalam bukunya berjudul "De Atjehers" menyatakan bahwa: Hukum adat adalah adat yang mempunyai sanksi, sedangkan adat yang tidak mempunyai sanksi adalah merupakan kebiasaan normatif, yaitu kebiasaan yang terwujud sebagai tingkah laku dan berlaku di dalam masyarakat. Pada kenyataan antara hukum adat dengan adat kebiasaan itu batasnya tidak jelas.

Pengertian hukum adat menurut Prof. Dr. Cornellis Van Vollenhoven sebagai seorang yang pertama-tama menjadikan hukum adat sebagai ilmu pengetahuan, sehingga hukum adat menjadi sejajar kedudukannya dengan hukum lain di dalam ilmu hukum menyatakan sebagai berikut: "Hukum adat adalah aturan-aturan perilaku yang berlaku bagi orang pribumi dan orang-orang timur asing yang disatu pihak mempunyai sanksi (maka dikatakan sebagai hukum) dan dilain pihak tidak dikodifikasikan (maka dikatakan adat).

Pengertian hukum adat menurut Soejono Soekanto, beliau menyatakan bahwa hukum adat adalah "hukum adat pada hakikatnya merupakan hukum kebiasaan, artinya kebiasaankebiasaan yang mempunyai akibat hukum. Kebiasaan yang merupakan hukum adat adalah perbuatan yang diulang-ulang dalam bentuk yang sama" .

Hukum adat merupakan hukum tradisional masyarakat yang merupakan perwujudan dari suatu kebutuhan hidup yang nyata serta merupakan salah satu cara pandangan hidup yang secara keseluruhannya merupakan kebudayaan masyarakat tempat hukum adat tersebut berlaku. Hukum adat juga merupakan nilai-nilai yang hidup dan berkembang di dalam masyarakat suatu daerah. Walaupun sebagian besar hukum adat tidak tertulis, namun ia mempunyai daya ikat yang kuat dalam masyarakat.

Ada sanksi tersendiri dari masyarakat jika melanggar aturan hukum adat. Hukum adat yang hidup dalam masyarakat ini bagi masyarakat yang masih kental budaya aslinya akan sangat terasa. Penerapan hukum adat dalam kehidupan sehari-hari juga sering diterapkan oleh masyarakat. Bahkan seorang hakim, jika ia menghadapi sebuah perkara dan ia tidak dapat menemukannya dalam hukum tertulis, ia harus dapat menemukan hukumnya dalam aturan yang hidup dalam masyarakat, artinya hakim juga harus mengerti perihal hukum adat. Hukum adat dapat dikatakan sebagai hukum perdatanya masyarakat Indonesia.

Dari pengertian Hukum Adat yang diungkapkan di atas, bentuk Hukum Adat sebagian besar adalah tidak tertulis. Padahal, dalam sebuah negara hukum, berlaku sebuah asas yaitu asas legalitas. Asas legalitas menyatakan bahwa tidak ada hukum selain yang dituliskan di dalam hukum. Hal ini untuk menjamin kepastian hukum. Namun di suatu sisi bila hakim tidak dapat menemukan hukumnya dalam hukum tertulis, seorang hakim harus dapat menemukan hukumnya dalam aturan yang hidup dalam masyarakat. Diakui atau tidak, namun Hukum Adat juga mempunyai peran dalam Sistem Hukum Nasional di Indonesia. Hukum adat yang dimaksud disini adalah hukum yang tidak tertulis tercantum pada pasal 25 (1) dan pasal 28 (1) dalam Undang-Undang tentang ketentuan -ketentuan pokok kekuasaan kehakiman nomor 4 
tahun 2004 yang menjelaskan pada intinya memungkinkan bahwasanya hukum adat yang tidak tertulis bisa menjadi dasar Hakim dalam menjatuhkan suatu putusan.

\section{Perbedaan Antropologi Hukum, Sosiologi Hukum dan Hukum Adat}

\section{a. Perbedaan Antropologi Hukum dan Sosiologi Hukum}

\begin{tabular}{|l|l|l|l|}
\hline No & Jenis & Antropologi Hukum & Sosiologi Hukum \\
\hline $\mathbf{1}$ & Kajian & $\begin{array}{l}\text { Mengkaji hukum dengan } \\
\text { mempelajari hukum dengan latar } \\
\text { belakang budayanya seperti } \\
\text { sejarah,lingkungan hidup, } \\
\text { keluarga, pemukiman, politik dsb. }\end{array}$ & $\begin{array}{l}\text { Mengkaji hubungan timbal } \\
\text { balik antara hukum dan gejala } \\
\text { sosial yg ada di dalam } \\
\text { masyarakat yang dilakukan } \\
\text { secara analitis dan empiris } \\
\text { (sesuai dengan } \\
\text { kenyataannya). }\end{array}$ \\
\hline $\mathbf{2}$ & Kelebihan & $\begin{array}{l}\text { Melalui kajian antropolgi maka } \\
\text { hukum dapat di ketahui latar } \\
\text { belakang kebudayaanya. }\end{array}$ & $\begin{array}{l}\text { Objek yang di kaji benar- } \\
\text { benar sesuai kenyataan, dan } \\
\text { tidak bersifat spekulatif. }\end{array}$ \\
\hline $\mathbf{3}$ & Kelebihan & $\begin{array}{l}\text { Menghasilkan pola dan } \\
\text { penyelesaian dari pada sengketa- } \\
\text { sengketa yang terjadi di dalam } \\
\text { masyarakat }\end{array}$ & $\begin{array}{l}\text { Diketahui } \\
\text { menyebabkan masyarakat } \\
\text { patuh atau tidak mentaati } \\
\text { hukum tersebut. }\end{array}$ \\
\hline $\mathbf{4}$ & Kekurangan & $\begin{array}{l}\text { Terletak pada ketidak } \\
\text { seragamannya hukum dan proses } \\
\text { penyelesaian masalah karena } \\
\text { berdasarkan latar belakang } \\
\text { kebudayaan dari hukum itu } \\
\text { sendiri. }\end{array}$ & $\begin{array}{l}\text { yanga } \\
\text { hubungan timbal balik antar } \\
\text { akan tetapi tidak mengkaji } \\
\text { faktor yang menyebabkan } \\
\text { penyimpangan dari hukum itu } \\
\text { sendiri }\end{array}$ \\
\hline
\end{tabular}




\begin{tabular}{|c|c|c|c|}
\hline 5 & Proses & $\begin{array}{l}\text { Awalnya temukan dulu faktanya } \\
\text { (Social facts), kemudian dipilah- } \\
\text { pilah } \\
\text { mana yang merupakan budaya } \\
\text { hukum, lalu dibuat konstruksi } \\
\text { hukumnya dan terakhir dianalisis } \\
\text { untuk ditemukan maknanya yang } \\
\text { mempunyai ciri-ciri khusus, } \\
\text { sebagai penjabaran dari jalinan } \\
\text { nilai budaya }\end{array}$ & $\begin{array}{l}\text { Awalnya temukan faktanya } \\
\text { (social facts) kemudian } \\
\text { dipilahpilah mana yang } \\
\text { merupakan kenyataan hukum } \\
\text { lalu dibuat } \\
\text { konstruksi hukumnya, } \\
\begin{array}{l}\text { selanjutnya dianalisis dengan } \\
\text { perundang-undangan/kaedah } \\
\text { hukumnya, terakhir } \\
\text { disimpulkan }\end{array} \\
\end{array}$ \\
\hline & & hukum & $\begin{array}{l}\text { apakah sesuai atau tidak } \\
\text { dengan perundang- } \\
\text { undangan/kaedah } \\
\text { hukumnya (efektivitas } \\
\text { hukum/kepatuhan hukum) }\end{array}$ \\
\hline 6 & Objek & Hukum bukan Barat, Tidak tertulis & $\begin{array}{l}\text { Hukum barat / yang telah } \\
\text { dipengaruhi hukum tertulis }\end{array}$ \\
\hline 7 & Subjek & Masyarakat Sederhana & Masyarakat Modern \\
\hline 8 & Persepektif & Budaya & Sosial \\
\hline 9 & Penelitian & Kualitatif , Studi Kasus & Kuantitaif, Sampel \\
\hline
\end{tabular}

\section{b. Pembedaan Antropologi Hukum dan Hukum Adat}

\begin{tabular}{|l|l|l|l|}
\hline No & Jenis & Antropologi Hukum & Hukum Adat \\
\hline $\mathbf{1}$ & Objek & Perilaku Manusi. & Norma Hukum di luar UU \\
\hline $\mathbf{2}$ & Pedekatan & Holistik & Yuridis Normatif \\
\hline $\mathbf{3}$ & Sifat Penelitian & Penelitian Lapangan & Studi pustaka dan dokumen \\
\hline $\mathbf{4}$ & Norma & Kenyataan & Dikehendaki \\
\hline
\end{tabular}

\section{C.PENUTUP}

Berdasarkan pembahasan di atas, dapat ditarik kesimpulan sebagai berikut ini:

1. Antropologi hukum adalah ilmu pengetahuan yang berkaitan dengan manusia yang bersangkutan dengan hukum.Antropologi hukum pada dasarnya mempelajari hubungan timbal-balik antara 
hukum dengan fenomena-fenomena sosial secara empiris dalam kehidupan masyarakat; bagaimana hukum berfungsi dalam kehidupan masyarakat, atau bagaimana hukum bekerja sebagai alat pengendalian sosial (social control) atau sarana untuk menjaga keteraturan sosial (social order) dalam masyarakat.

2. Sosiologi hukum merupakan studi hukum dalam perspektif ilmu sosial merupakan sebuah ikhtiar melakukan konstruksi hukum yang didasarkan pada fenomena sosial yang ada. Perilaku masyarakat yang dikaji adalah perilaku yang timbul akibat berinteraksi dengan sistem norma yang ada. Interaksi itu muncul sebagai bentuk reaksi masyarakat atas diterapkannya sebuah ketentuan perundangundangan positif dan bisa pula dilihat prilaku masyarakat sebagai bentuk aksi dalam memengaruhi pembentukan sebuah ketentuan hukum positif. kajian sosiologi hukum adalah suatu kajian yang objeknya fenomena hukum, tetapi menggunakan optik ilmu sosial dan teori-teori sosiologis, sehingga sering disalahtafsirkan bukan hanya oleh kalangan non hukum, tetapi juga dari kalangan hukum sendiri.

3. Hukum adat merupakan hukum asli Indonesia yang tidak terkodifikasi dalam peraturan perundangundangan nasional. Hukum adat merupakan hukum tradisional masyarakat yang merupakan perwujudan dari suatu kebutuhan hidup yang nyata serta merupakan salah satu cara pandangan hidup yang secara keseluruhannya merupakan kebudayaan masyarakat tempat hukum adat tersebut berlaku. Hukum adat juga merupakan nilai-nilai yang hidup dan berkembang di dalam masyarakat suatu daerah. Ada sanksi tersendiri dari masyarakat jika melanggar aturan hukum adat.

\section{DAFTAR PUSTAKA}

Gokma Toni Parlindungan S, Asas Nebis In Idem Dalam Putusan Hakim Dalam Perkara Poligami Di Pengadilan Negeri Pasaman Sebagai Ceriminan Ius Constitutum, Volume 2, Nomor 1, 2020.

Gokma Toni Parlindungan S, Pengisian Jabatan Perangkat Nagari Pemekaran Di Pasaman Barat Dalam Rangka Pelaksanaan Otonomi Daerah, Ensiklopedia Of Journal, Vol 1 No 2 Edisi 2 Januari 2019,

Harniwati, Peralihan Hak Ulayat Menurut Undang-Undang Nomor 18 Tahun 2004, Volume 1, Nomor 3, 2019.

Jasmir, Pengembalian Status Hukum Tanah Ulayat Atas Hak Guna Usaha, Soumatera Law Review, Volume 1, Nomor 1, 2018. 
Jumrawarsi Jumrawarsi, Neviyarni Suhaili, Peran Seorang Guru Dalam Menciptakan Lingkungan Belajar Yang Kondusif, Ensikopedia Education Review, Vol 2, No 3 (2020): Volume 2 No.3 Desember 2020

Mia Siratni, Proses Perkawinan Menurut Hukum Adatdi Kepulauan Mentawai Di Sebelum Dan

Sesudah Berlakunya Undang-Undang Nomor 1 Tahun 1974 Tentang Perkawinan, Ensiklopedia Of Journal, Vol 1 No 2 Edisi 2 Januari 2019,

Remincel, Dimensi Hukum Pelanggaran Kecelakaan Lalu Dan Angkutan Jalan Lintas Di Indonesia, Ensiklopedia Social Review, Volume 1, Nomor 2, 2019.

R Amin, B Nurdin, Konflik Perwakafan Tanah Muhammadiyah di Nagari Singkarak Kabupaten Solok Indonesia 2015-2019, Soumatera Law Review, Volume 3, Nomor 1, 2020. 